\title{
KAJIAN MASYARAKAT PULUTAN SEBAGAI PERAJIN KERAMIK UNTUK MENINGKATKAN EKONOMI KELUARGA (Studi Kasus Ibu Rumah Tangga Sebagai Perajin Keramik Tradisional Di Desa Pulutan Kecamatan Remboken)
}

\author{
Jovelien Janz Neltje Laloan
}

\begin{abstract}
This study is comprised of housewives who are in the Village Pulutan in SubDistrict Remboken who jumped on the small industries or home industries that are working in addition to their regular job as a housewife, which are taking care their husband and children, cooking, washing clothes etc. as the core power in the house. Based on the obtained data show that the highest incomes above, then the above three million of 11 respondents or 61,1 percent, then the above Rp 2 million of 5 responder or 27,7percent, then at over 1,000.000 a respondent stayed 2 or 11,1 per cent. Looking at the distribution of income is the highest number of respondents 11

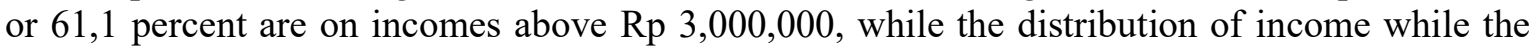
lowest in over one million is a number 2 or 11,1 percent of the respondents is the lowest income of the respondent. It turned out that the above data show that with no additional work for housewives there was an increase in revenue. Conclusions through the research found that respondents family income has increased because most income is through the work of the husbands of various professions coupled with the work of housewives. As a suggestion to the community artisans to maintain quality and enhance the creative and innovate to be ready to compete to further develop the marketing area for both national and international level.Government be expected to pay attention to the industry in order to the needs of craftsmen, especially the need of capital for developing businesses and increasing skills through training in accordance with technological advances.
\end{abstract}

Keywords: Community Craft, Ceramics.

Pendahuluan

$(\mathrm{SDM})$
Pengembangan sumber daya manusia disegala bidang, pada dasarnya 
mengikutsertakan partisipasi seluruh lapisan masyarakat, baik laki-laki maupun perempuan kenyataan dalam pelaksanaannya selama ini menunjukkan bahwa proses dan tahapan pembangunan kurang mengikutsertakan perempuan, meskipun potensi perempuan sangat besar.

Model pembangunan yang dapat mengakomodir kepentingan perempuan dapat diwujudkan dengan mengintegrasikan perempuan ke dalam pembangunan. Pendekatan ini lebih dikenal dengan Women in Development (WID), di mana melalui pendekatan ini perempuan diharapkan tampak dan diterima keberadaannya dengan karakteristik bahwa perempuan yang ikut dalam pembangunan tidak boleh melupakan peranan keibuannya sebagai kodrat perempuan.

Karakteristik perempuan yang ikut bergabung dalam pembangunan adalah yang dapat mensejajarkan kodrat keibuannya dengan mobilitasnya dalam pembangunan. Kodrat ibu mendidik anak-anaknya untuk tumbuh menjadi generasi yang baik sehingga mampu menjadi penerus pembangunan. Peningkatan peran wanita terutama dalam bidang ekonomi akan sangat berarti bagi pembangunan yang sedang dilaksanakan sekarang ini.

\section{Metode Penelitian}

Penelitian yang dilaksanakan terhadap para ibu rumah tangga adalah sebagai wanita pekerja selain mengerjakan tugas rutinitas dalam keluarga tetapi juga bekerja sebagai perajin keramik untuk menambah pendpatan keluarga.

Untuk memperoleh data maka pengumpulan data dijaring dengan penarikan sampel secara proporsional (Purposive sampling) yaitu hanya pada keluarga yang terlibat langsung pada perajin keramik, dengan melakukan wawancara secara mendalam, terhadap para informan, dengan mengunjungi lokasi penelitian dengan door to door para responden. Melihat langsung bagaimana cara mengolah mulai dari bahan baku sampai menjadi satu produksi yang siap dipasarkan.

Hasil dari lapangan dikumpulkan baik data melalui angket, wawancara langsung, disusun secara sistematis kemudian analisis dan kemudian diambil suatu kesimpulan tertentu berdasarkan karegori jawaban yang diperoleh dari lapangan.

\section{Hasil dan Pembahasan \\ 1. Keadaan Responden}

Para responden yang berjumlah 18 orang dan mempunyai anggota keluarga yang berbeda sehingga untuk kebutuhan sehari-hari juga pasti berbeda, mengenai pendapatan dari masingmasing responden juga berbeda karena baik kemampuan bekerja dan curahan jam kerja juga disesuaikan dengan kegiatan rutin dari responden itu sendiri.

\section{Penghasilan atau Pendapatan Responden}

Penghasilan atau pendapatan responden yang dimaksud adalah yang diperoleh baik dari pihak suami yang terjun pada berbagai bidang pekerjaan dan dari para responden itu sendiri.

Pada data menunjukkan bahwa pendapatan tertinggi di atas di atas Rp 3.000.000 sejumlah 7 atau 38,8 persen responden, di atas $\mathrm{Rp} 2.000 .000$ sejumlah 7 atau 38,8 persen, dan yang diatas $\mathrm{Rp} 1.000 .000$ sejumlah 4 atau 22,2 persen, data ini adalah masih hasil dari suami atau kepala keluarga.

Setelah ditambah dengan hasil istri, data menunjukkan bahwa yang memperoleh pendapatan tertinggi di atas di atas 3.000.000 sejumlah 11 responden atau 61,1 persen, kemudian di atas Rp 2.000.000 sejumlah 5 atau 27,7 , kemudian di atas 1.000 .000 sejumlah tinggal 2 responden atau 11,1 persen. Melihat penyebaran pendapatan responden yang terbanyak sejumlah 11 atau 61,1 persen adalah pada pendapatan di atas Rp 3.000.000, sedangkan sedangkan penyebaran pendapatan yang terendah di atas 1.000.000 adalah sejumlah 2 responden atau 11,1 persen adalah merupakan pendapatan yang terendah dari responden. Ternyata pada data di atas menunjukkan bahwa dengan ada pekerjaan tambahan bagi ibu rumah tangga ternyata ada peningkatan pendapatan .

\section{Simpulan dan Saran}

Berdasarkan hasil penelitian bahwa menunjukkan ada peningkatan pendapatan dari keluarga responden dapat dilihat pada data 
bahwa yang memperoleh pendapatan, di atas $\mathrm{Rp}$ 3.000.000 sejumlah 7 responden meningkat menjadi 11 responden atau 61,1 persen, di atas Rp 2.000.000 sejumlah 7 responden menjadi 5 responden atau 27,7 persen dan yang di atas Rp 1.000.000 sejumlah 2 atau 11,1 persen, atau merupakan pendapatan yang terendah dari responden.

Sebagai saran kepada pemerintah supaya dapat memperhatikan masyarakat perajin keramik. Para masyarakat perajin keramik supaya lebih berkreatif dan berinovasi terutama mempertahankan kualitas bahan baku supaya nilai ekonomis akan lebih tinggi dan dapat dipasarkan lebih luas bukan hanya tingkat nasional kalau perlu ke pasar internasional.

\section{Daftar Pustaka}

Anonim, 2006, Voicess of Women in the Private Sector, Jakarta, ILO.

Anonim, 2007, Perajin Keramik Bayat Klaten Mulai Bangkit, w.w.kapanlagi.com/h/0000172701.html. Anonim, 2009, Melihat Kondisi di Industri, w.w.studiokeramik.org/2008/04/melihatkondisi-di industri.html.

Nuraeni. E, 2008, Perempuan dan Program Pemanfaatan Tumbuhan Obat

Di Taman Nasional Menu Betiri Jember Jawa Timur,

16 September 2011.

Pingky \& Budiyanto B, 1994, Wanita, Kerajinan Bambu dan Masyarakat, Jogyakarta.

Saljo. S, 1995, Implikasi-implikasi Sosial Budaya Dari Wanita Yang Bekerja, Jakarta, Makalah.

Suratiyah dkk, 1991, Wanita Kerja Dan Rumah Tangga, Jogyakarta, Penelitian

Viane, 2006, Women, Gender and Work in Nenggroe Aceh Darussalam Province, ILO Working Paper.

-----------, 2006, Acces to Finance For Womens Entrepreneurs, Unfortunately noProWomen Bank Exists in Banda Aceh, Unpublished ILO Report. 